\title{
Problems in the Implementation of Corporate Social Responsibility of Forestry and Plantation Companies in Pelalawan District
}

\section{Hasnati and Andrew Shandy Utama}

Faculty of Law, Lancang Kuning University, Pekanbaru, Indonesia

\section{Abstract}

Companies that carry out their business activities in the field of natural resources and / or fields related to natural resources must carry out corporate social responsibility. In Pelalawan District there are 33 large companies whose business activities are in the forestry and plantation industries with an investment value of trillions of rupiah. In fact, the implementation of corporate social responsibility of these companies is very little felt by the community. What are the problems in the implementation of corporate social

Corresponding Author: Andrew Shandy Utama andrew.fh.unilak@gmail.com

Received: 18 January 2019 Accepted: 24 March 2019 Published: 31 March 2019

Publishing services provided by Knowledge E

(c) Hasnati and Andrew Shandy Utama. This article is distributed under the terms of the

Commons Attribution License, which permits unrestricted use and redistribution provided that the original author and source are credited.

Selection and Peer-review under the responsibility of the First ELEHIC Conference Committee. responsibility of forestry and plantation companies in Pelalawan District? The method used in this research is socio-legal research. The results of this research are that the problems in the implementation of corporate social responsibility of forestry and plantation companies in Pelalawan District due to the absence of regional regulations specifically regulating corporate social responsibility in Pelalawan District, the lack of legal knowledge of the community of Pelalawan District regarding Law Number 25 of 2007 and Law Number 40 of 2007, and there are no strict sanctions for companies that do not implement corporate social responsibility.

Keywords: corporate social responsibility, implementation, problems

\section{Introduction}

A company is a legal entity which is a capital alliance, established based on an agreement, conducts business activities with authorized capital which is entirely divided into shares, and fulfills the requirements stipulated by the law and its implementing regulations. The main goal of a company is to seek maximum profits. This is the responsibility of the management of the company to shareholders as the owner of the company. This is the philosophical basis of establishing a company. However, the company's operational activities in order to maximize profits are often detrimental to the community, especially the people who live around the location of the company [1]. 
According to the perspective of business law, there are two responsibilities that must be implemented in business ethics, namely legal responsibility and social responsibility. Legal responsibility includes the civil and criminal aspects, while social responsibility means that the company is not only a business entity that seeks profit, but is a unit with the social, economic and environmental conditions in which the company operates [2]. Business ethics can bridge the interests of the company with the needs of the community, both those directly and indirectly affected by the company's operations. So, business ethics is the basis of the birth of the concept of corporate social responsibility [3].

Corporate social responsibility is motivated by the concept of sustainable development which was formulated at an international conference in Stockholm in 1982 [4]. The World Business Council for Sustainable Development explains that corporate social responsibility is the commitment of the company to operate legally and ethically, contribute to improving the economy and the quality of life of its employees, as well as improving the quality of life of local communities [5].

This research was conducted in Pelalawan District, Riau Province. From the observations made, it is known that in Pelalawan District there are 33 large companies whose business activities are in the forestry and plantation industries with investment value reaching trillions of rupiah, one of which is PT Riau Andalan Pulp \& Paper with an investment value of 26.6 trillion rupiah.

Based on Article 74 of Law Number 40 of 2007, it is affirmed that companies that carry out their business activities in the field of natural resources and / or fields related to natural resources must implement corporate social responsibility. In fact, the implementation of corporate social responsibility of large companies is very minimal felt by the community of Pelalawan District. According to data from the Pelalawan Regency Central Bureau of Statistics in 2015, it was stated that $12 \%$ of the people in Pelalawan Regency were categorized as poor, with 44,127 people. This number makes Pelalawan District the region with the second largest number of poor people in Riau Province. This is certainly very contrary to the large number of forestry and plantation industry companies in Pelalawan District.

From the background described above, what are the problems in the implementation of corporate social responsibility of forestry and plantation companies in Pelalawan District? 


\section{Method of Research}

The method used in this research is socio-legal research. The data sources used in this research are primary data and secondary data. Data collection techniques used in this research were observation, interviews, and library studies. The data analysis technique used in this research is qualitative analysis.

\section{Result of Research and Discussion}

In 2007 , there were significant changes regarding corporate social responsibility in the national legal system in Indonesia after the enactment of Law Number 25 of 2007 about Investment and Law Number 40 of 2007 about Limited Liability Companies. Law Number 25 of 2007 and Law Number 40 of 2007 have changed the paradigm regarding corporate social responsibility from voluntary to legal obligations for companies [6].

The enactment of Law Number 25 of 2007 aims to ensure that the rights, obligations and responsibilities of investors are specifically regulated to provide legal certainty, reinforce the obligations of investors to apply the principles of sound corporate governance, give respect to the cultural traditions of the community, and implement corporate social responsibility. Provisions regarding corporate social responsibility are strictly regulated in Article 15 of Law Number 25 of 2007, which confirms that every investor is obliged to carry out corporate social responsibility.

In line with that, the enactment of Law Number 40 of 2007 aims to realize sustainable economic development to improve the quality of life and the environment that benefits the company itself, the local community, and society in general. Provisions regarding corporate social responsibility are strictly regulated in Article $\mathbf{7 4}$ of Law Number 40 of 2007, which confirms that companies that carry out their business activities in the field of natural resources and / or fields related to natural resources must implement corporate social responsibility.

In Pelalawan District there are 33 large companies, local companies and foreign companies, whose business activities are in the forestry and plantation industries with an investment value of trillions of rupiah. Local companies in Pelalawan District include PT Riau Andalan Pulp \& Paper with an investment value of 26.6 trillion rupiah located in Pangkalan Kerinci Sub-district, PT Riau Prima Energi with an investment value of 7.1 trillion rupiah located in Pangkalan Kerinci Sub-district, and PT Musim Mas with an investment of 1 trillion rupiah located in Pangkalan Kuras Sub-district and Pangkalan 
Lesung Sub-district. Meanwhile, foreign companies in Pelalawan District include PT Intiguna Prima Tama with an investment value of 11.3 trillion rupiah located in Pangkalan Kerinci Sub-district, PT Riau Andalan Kertas with an investment value of 7.1 trillion rupiah located in Pangkalan Kerinci Sub-district, PT TH Indo Plantations has an investment of 3.8 trillion rupiah located in Teluk Meranti Sub-district, PT Anugerah Kertas Utama with an investment of 2.2 trillion rupiah located in Pangkalan Kerinci Sub-district, and PT Adei Plantations \& Industry with an investment value of 1.2 trillion rupiah located in Pangkalan Kuras Sub-district, Pelalawan Sub-district, and Bunut Sub-district.

In South Solok District, the implementation of corporate social responsibility that has been well programmed by PT Visi Utama Mandiri has a positive impact on the community. There are two programs, namely physical programs and non-physical programs. The physical program carried out in the form of assistance for road construction, road repairs, supporting victims of natural disasters, renovation of places of worship, sports facilities, and monthly financial assistance for community groups. Meanwhile, the nonphysical programs implemented were in the form of health education and entrepreneurship training for the community [7]. Meanwhile in the Pekanbaru City, PT Riau Crumb Rubber Factory does not carry out corporate social responsibility to the people who live around the location of the company, but the community never issues. This is because PT Riau Crumb Rubber Factory prioritizes the people of Sri Meranti Village to be recruited as laborers at the company [8].

The implementation of corporate social responsibility must be integrated into community development activities, consumer protection, healthy business, environmental sustainability, employment, human rights, and government programs. The substance of the existence of corporate social responsibility is to strengthen the sustainability of the company by building cooperation with stakeholders through community empowerment programs [9].

PT Riau Andalan Pulp \& Paper as the largest forestry industry company in Pelalawan District every year routinely carries out corporate social responsibility to the people who live around the company's location. The corporate social responsibility program implemented by PT Riau Andalan Pulp \& Paper, namely [10]:

1. Integrated farming system, which is giving assistance to planters who are entrepreneurs in agriculture and plantations as well as fish seeds to people who are entrepreneurs in the fisheries sector.

2. MSMEs, namely the provision of financial assistance to people who are selfemployed. 
3. Social infrastructure, namely the construction and renovation of public infrastructure.

4. Education, which is providing educational scholarships to outstanding students.

5. Vocational training, which is providing technical training to the younger generation.

6. Employee volunteerism, which is employee volunteerism in helping the surrounding community.

The problems that caused the implementation of the corporate social responsibility of forestry and plantation industry companies in Pelalawan District did not work optimally due to the absence of regional regulations specifically regulating corporate social responsibility in Pelalawan District. With the absence of these regional regulations, there is no automatic government agency in Pelalawan District which is tasked with carrying out oversight of the implementation of corporate social responsibility of forestry and plantation industry companies in the surrounding communities.

Other problems that led to the implementation of corporate social responsibility of forestry and plantation industry companies in Pelalawan District did not work optimally due to the lack of legal knowledge of the Pelalawan District community regarding Law Number 25 of 2007 and Law Number 40 of 2007. People do not know that corporate social responsibility is an obligation that must be carried out by the company. The community considers corporate social responsibility to be only a voluntary assistance from the company to the community, so that the community does not mind if the companies do not carry out corporate social responsibility.

In addition, the absence of strict sanctions for companies that do not implement corporate social responsibility has led to the implementation of corporate social responsibility of forestry and plantation industry companies in Pelalawan District not running optimally. Based on Article 74 of Law Number 40 of 2007 it is stated that companies that do not implement corporate social responsibility will be subject to sanctions in accordance with the provisions of the legislation. In Law Number 40 of 2007 it should be regulated regarding strict administrative sanctions such as freezing operational licenses and criminal sanctions for companies that do not carry out corporate social responsibility to people who live around the company's location.

The implementation of corporate social responsibility is part of the good corporate governance framework because corporate social responsibility programs as a form of corporate social solidarity are not only beneficial to the community, but also very useful for shaping the company's image when packaged with proper publications [11]. 
The success of a region in improving the welfare of its population can be realized if all components of the community take part, including real participation from companies operating in the area [12].

\section{Conclusion}

Companies that carry out their business activities in the field of natural resources and / or fields related to natural resources must carry out corporate social responsibility. In Pelalawan District there are 33 large companies whose business activities are in the forestry and plantation industries with an investment value of trillions of rupiah. In fact, the implementation of corporate social responsibility of these companies is very little felt by the community. The problem is due to the absence of regional regulations specifically regulating corporate social responsibility in Pelalawan District, the lack of legal knowledge of the community of Pelalawan District regarding Law Number 25 of 2007 and Law Number 40 of 2007, and the absence of strict sanctions for companies that do not implement corporate social responsibility.

\section{Acknowledgement}

The researcher thanked the Rector of Lancang Kuning University for giving permission for researchers to conduct this research. The researcher also thanked the Dean of the Law Faculty of Lancang Kuning University for giving moral support to researchers to complete this research.

\section{Funding}

The researcher thanked the Rector of Lancang Kuning University for providing financial assistance to researchers to complete this research.

\section{References}

[1] Fahmi. (2011). Corporate Social Responsibility, From Moral Responsibility Towards Social Justice Legal Responsibility. Respublica Journal, Vol. 11, No. 1, pp. 16-31.

[2] Khairandy, R. (2009). Limited liability company; Doctrine, Legis/ation and Jurisprudence. Yogyakarta: Kreasi Total Media. 
[3] Fahmi. (2015). Shifting Corporate Social Responsibility; From Moral Responsibility to Legal Responsibility. Yogyakarta: FH UII Press.

[4] Ferdi. (2009). International Legal Aspects in Regulating Corporate Social Responsibility. Respublica Journal, Vol. 8, No. 2, pp. 224-231.

[5] Salim. dan Nurbani, E. S. (2016). Application of Legal Theory in Dissertation and Thesis Research. Jakarta: Rajawali Pers.

[6] Firdaus. (2010). Corporate Social Responsibility; Transforming Morals into Law in Building Community Welfare. IImu Hukum Journal, Ed. 1, No. 1, pp. 16-30.

[7] Herlina, Y. Oktavia, D. A. dan Elvawati. (2014). The implementation of Corporate Social Responsibility (CSR) Programs of PT Visi Utama Mandiri in Sungai Kunyit Sub-village, South Solok District. Mamangan Journal, Vol. III, No. 1, pp. 10-17.

[8] Utama, A. S. dan Rizana. (2017). Implementation of Corporate Social Responsibility of PT Riau Crumb Rubber Factory towards the Society of Sri Meranti Village, Pekanbaru City. Novelty Journal, Vol. 8, No. 2, pp. 173-186.

[9] Sembiring, S. (2009). Social and Environmental Responsibility in the Corporate Legal Perspective. Yustisia Journal, Ed. 77, Th. XX, pp. 66-72.

[10] Utama, A.S. (2018). Implementation of Corporate Social Responsibility of PT Riau Andalan Pulp and Paper on Communities in Pelalawan District. Selat Journal, Vol. 5, No. 2, pp. 123-133.

[11] Yetti. (2007). Corporate Social and Environment Responsibility Based on Law Number 40 of 2007 about Limited Liability Companies. Respublica Journal, Vol. 7, No. 1, pp. $113-118$.

[12] Siregar, L. and Ihsan, R. (2013). Application of Provisions for Corporate Social Responsibility (CSR) in Private Companies. Ius Journal, Vol. I, No. 2, pp. 220-234. 